\title{
Relationship among Different Secondary Traits and Seed Yield in Cowpea (Vigna unguiculata L. Walp)
}

\author{
R.R. Das*, P. Talukdar, Praveen Kumar and S.B. Neog \\ Department of Plant Breeding and Genetics, Assam Agricultural University, \\ Jorhat-785013, India \\ *Corresponding author
}

A B S T R A C T

\begin{tabular}{|c|}
\hline Keywords \\
\hline $\begin{array}{l}\text { Correlation, } \\
\text { Cowpea, } \\
\text { Genotypes, } \\
\text { Interrelationship, } \\
\text { Path analysis }\end{array}$ \\
\hline Article Info \\
\hline $\begin{array}{l}\text { Accepted: } \\
\text { 15 January } 2018 \\
\text { Available Online: } \\
\text { 10 February } 2018\end{array}$ \\
\hline
\end{tabular}

Seed yield is the primary trait of interest, however, several secondary traits contributes in final yields. Contribution of various traits varies significantly, and therefore, identification of traits with their level of contribution into seed yield might help breeders in selection of high yielding cowpea varieties with simultaneous selection for seed along with trait(s) with higher contribution in final yields. We studied range of key secondary traits along with seed yield in cowpea genotypes to understand the hierarchy of contribution of various traits in seed yield. Analysis of variance revealed presence of significant variation among the genotypes for all the characters studied. Genetic coefficient of variation, heritability and genetic advance was high for seed yield. Path coefficient analysis clearly revealed that clusters of pod per plant exhibited maximum direct positive effect on seed yield per plant both at phenotypic and genotypic levels. However, pod length followed by plant height, test weight and pods per cluster exhibited negative direct effect phenotypically. We conclude that among various traits the clusters of pod per plant might be considered as a potential character contributing towards increasing seed yield which could be used as selection criteria along with seed yield for genetic improvement of cowpea genotypes.

\section{Introduction}

Cowpea [Vigna unguiculata (L.) Walp.] is one of the most important pulse crops native to Central Africa and belongs to the family Leguminaseae genus Vigna, subfamily fabaceae and tribe phaseoleae. It comprises five subspecies (Verdcourt, 1970) viz., unguiculata, cylindrical, sesquipedalis, dekindtiana and mensensis in phaseolae. Out of these five subspecies first three are cultivated and later two are wild. It is a selfpollinated crop with a chromosome no.
$2 n=2 x=22$. Cowpea is also considered as vegetable meat due to its high amount of protein in grain with better biological value on dry weight basis. Apart from this, cowpea forms excellent forage and it gives a heavy vegetative growth and covers the ground so well that it checks the soil erosion. As a leguminous crop, it fixes about $70-240 \mathrm{~kg}$ per ha of nitrogen per year. As a pulse crop, cowpea fits well into most of the cropping systems including crop-rotation practices for soil health. Cowpea is the most economically important indigenous African legume crop 
and has a wide variety of uses as a nutritious component in the human diet as well as nutritious livestock feed (Langyintuo et al., 2003).

Additionally cowpea is a valuable component of farming systems in many areas because of its ability to restore soil fertility for succeeding cereal crops grown in rotation with it (Carsky et al., 2002). An estimated 14.5 million hectares of land is planted to cowpea each year worldwide. Global production of dried cowpeas in 2010 was 5.5 million metric tons; Africa was responsible for 94 per cent of this. Nigeria is the largest producer and consumer of cowpea producing 2.2 million metric tons of dried grain in 2010 . The average yield worldwide is estimated at 450 kilograms per hectare. The available statistics of cowpea in India reveals that the crop is harvested over an area of 0.59 million ha in 2006-08. However, there is no authentic data on area and production of cowpea in Assam and N.E. India. The crop is grown in this region particularly as a forage crop and for its green pods as a vegetable. There is scope to popularize cowpea in Assam and N.E. India as a seed crop or as a duel purpose crop.

Yield is a complex character, the result of the expression and association of different character, which are highly influenced by the environment (Amorim et al., 2008) in order to have a good choice of character for selection of desirable genotypes under planned breeding programme, knowledge of the nature and magnitude of variation existing in available plant breeding materials, the association of component characters with yield and their exact contribution through direct and indirect effects are very import-ant. Genotypic and different components of variance, heritability and genetic advance have been calculated for different yield characters in cowpea by several workers (Damarany, 1994; Uguru, 1995;
Pathmanathan et al., 1997; Umaharan et al., 1997; Ubi et al., 2001; Omoigui et al., 2006) which revealed that selection was effective for a population with broad genetic variability and character with high heritability. The correlation co-efficient gives, an idea of the nature and intensity of association between two or more quantitative characters between yield and yield contributing characters. Correlation simply measures that mutual relationship between yield and yield contributing characters. Thus, correlation helps in the selection of superior genotype from diverse genetic populations. Knowledge of correlation between yield and its contributing characters are basic and for most endeavour to find out guide lines for plant selection. Partitioning of total correlation into direct and indirect effects by path coefficient analysis helps in making the selection more effective. Thus providing understanding of the direct and indirect contribution of each character towards yield.

The north east India including Assam is particularly deficient in pulse crop production and is dependent on importing different pulse crops from other states of India. The major pulse crops of the state are blackgram, greengram, arhar, lentil and pea. Along with increased production there is also a need to diversify pulse crops with crops like cowpea and Lathyrus. Cowpea could be a potential pulse crop as it could be used both as seed crop as well as green pod vegetable in addition to its use as fodder crop. This will further encourage much needed diversification of pulse crops and there by accelerate growth in pulse production. Thus it is important to develop improved varieties adaptable to this region and suitable to fit into the existing cropping system of the region.

Thus, the aim of this study was to estimate the interrelationship among different quantitative characters to establish a causal relationship for seed yield. 


\section{Materials and Methods}

\section{Experimental site and materials}

The field experiment was conducted at Assam Agricultural University research farm, located in Jorhat, India. It is located at $26^{\circ} 44^{\prime} \mathrm{N}$ latitude and $94^{\circ} 10^{\prime} \mathrm{E}$ longitude, having an elevation of 86.6meter above the mean sea level. Experimental materials comprised of 6 parents and 15 crosses. Cowpea varieties used as parent along with their source are given in the Table 1. Parents and their $\mathrm{F}_{1}$ progenies were sown during $1^{\text {st }}$ week of October in a randomized block design with two replications. The data on prevailing weather condition is presented in Table 2 .

\section{Data collection and analysis}

Data on 10 randomly selected representative plants from each plot to records various traits, including - plant height, number of primary branches per plant, clusters of pod per plant, pods per cluster, seeds per pod, seed yield per plant and hundred seed weight. The replicated data for each character was subjected to analysis of variance. The partitioning of variance into different components was done in accordance with the following model.

$P_{i j}=m+g_{i}+e_{i j}$, Where, $P_{i j}$ is the $i j^{\text {th }}$ observation of the $i^{\text {th }}$ genotype; $\mathrm{m}$ is the general mean; $g_{i} i s$ the effect of $i^{\text {th }}$ genotype; $\mathrm{e}_{\mathrm{ij}}$ is the random error associated with $\mathrm{ij}^{\text {th }}$ observation. The genetic and phenotypic variances were computed as the formula suggested by Burton (1953).

Heritability in broad sense is the ratio of genetic variance $\left(\sigma_{\mathrm{g}}^{2}\right)$ to the phenotypic variance $\left(\sigma_{p}^{2}\right)$ expressed in percentage. It was calculated by using the following formula (Allard, 1960) and Expected genetic advance for each character was calculated by using the formula suggested by Hanson, Robinson and Comstock (1956). The genotypic and phenotypic correlation coefficients between two characters say $\mathrm{X}$ and $\mathrm{Y}$ under study were calculated. For this, the data was subjected to the analysis covariance and the respective correlation coefficients were computed.

The path analysis was worked out following the methodology proposed by Dewey and Lu (1959).

\section{Results and Discussion}

\section{Analysis of variance}

Analysis of variance for yield and yield attributing characters are presented in Table 3 . A Significant variation among the genotypes for all the characters under study was obtained.

On further partitioning, it is observed that the parents and the crosses showed significant variation for most of the characters except plant height, number of primary branches, pods per cluster, seeds per pod and pod length. Parent versus crosses variation was significant for all the characters except primary branches, pods per cluster and seeds per pod. Significant variability for yield and yield attributing characters in cowpea was also reported in previous studies (Drabo et al., 1984; Taiwo 1998; Olapade et al., 2002; Lopes et al., 2003; Yalcin, 2007). Further a comparison for the range of mean performance of the parents and those of the resultant progenies indicated transgressive segregation for almost all the characters. This has revealed considerable scope to exploit desirable recombinations for genetic improvement of cowpea.

\section{Estimation of genetic variance and related parameters}

The genotypic and phenotypic coefficients of variation, which are independent of units of measurements, were estimated along with 
heritability and genetic advance are presented in Table 4. In the present study, all these estimates clearly revealed not only the presence of sufficient variation at genotypic level but transmissibility of the variation to the progenies. Further the study also focussed those characters which were governed predominantly by additive genes.

For all the characters studied, estimates of phenotypic coefficients of variation (PCV's) were higher than genotypic coefficients of variation (GCV's) indicating effect of environment on the expression of the characters. However, a close examination of these estimates revealed greater difference between these two estimates for pod length, seeds per pod, pods per cluster, and plant height which indicated considerable effect of environment for these characters. This was also reflected in the lower heritability (h2) estimates of these characters. On the other hand, hundred seed weight, seed yield per plant, clusters of pod per plant and number of primary branches in that order revealed very close PCV and GCV estimates indicating insignificant role of environment in the expression of these characters. Their respective high h2 estimates corroborated the finding. It suggests that these characters are highly heritable and therefore the traits can be easily transferred from parent to offspring. Similar results were obtained by Kumar et al (2009) for plant height, pod length, 100 seed weight, grain yield per plant, number of branches and number of pods per plant; Shivakumar et al., (2013) for pod weight, plant height, and pod length; Shanko et al., (2014) for yield per plant, number of pods per plant, and 100-seed weight and Umaharan et al., (1997). Expected genetic advance (GA) was found high for plant height $(32.062 \%)$, number of primary branches $(29.455 \%)$, seed yield per plant $(21.685 \%)$ and clusters of pod per plant (21.511\%). Similar high GA was reported by Idahosa et al., (2010) for pod length, pod weight, seeds per pod and 100seed weight in cowpea.

Johnson et al., (1955) reported that heritability estimates together with genetic advance are more important than heritability alone to predict the resulting effect of selecting the best individuals. Hanson (1963) suggested that heritability estimates couldn't be considered as a stable population parameter as it differs under different sets of environment and is dependent on the degree of precision with which environmental variance is determined. Genotypic coefficient of variation together with broad-sense heritability could perhaps be a better index of the extent of advance that can be expected from gene selection scheme (Burton, 1952). Heritability combined with genetic advance is a more reliable index for selections of traits (Ubi et al., 2001). These observations were in agreement with the findings of Nehru et al., (2009) and Kumari et al., (2003). According to Ansari et al., (2004) high heritability percentage reflects the large heritable variance, which may offer the possibility of improvement through selection.

In the present study high genotypic coefficient of variation followed by high heritability and high genetic advance was obtained in characters number of primary branches, clusters of pod per plant and seed yield per plant. Therefore, besides seed yield per plant which is the economically valuable character, phenotypic selection for increased number of primary branches and increased clusters of pods per plant even without progeny testing might accumulate favourable additive genes controlling these characters.

\section{Mean performance}

The enhancement of seed yield is the primary objective for improvement of cowpea varieties for seed purpose. In Table 5 an 
assessment of six parents was done and it was found that JCC-4 exhibited the highest yield per plant. This parent also possessed the highest mean performance for other yield attributing characters like high clusters of pod per plant. Eventually, this parent transmitted its high yielding potential in to its cross progenies with other parents. The cross JCC-1 $\mathrm{x}$ JCC-4 followed by JCC-3 x JCC-4 showed the maximum yield per plant.

Besides JCC-4, the parent UPC-622 possessed best performance for shorter plant height, maximum number of pods per cluster, number of primary branches per plant, pod length, number of seeds per pod and hundred seed weight and the parent UPC-287 exhibited the maximum clusters of pod per plant. In addition to the crosses, JCC- $1 \mathrm{x}$ JCC-4 and JCC-3 x JCC-4, the cross UPC$622 \times$ UPC-287 exhibited best performance for maximum pods per cluster, seeds per pod and pod length; JCC-3 x JCC- 1 showed better performance for shorter plant height; JCC-2 $\mathrm{x}$ JCC-3 for maximum number of primary branches; JCC-3 x JCC-4 for maximum clusters of pod per plant and UPC$622 \times$ JCC-4showed maximum for hundred seed weight. Based on mean performances all these crosses showing higher performance for seed yield and one or more yield attributes could be potential material for selection to effect genetic improvement in cowpea

\section{Correlation coefficient}

Yield being a complex trait is dependent upon a number of components. Knowledge about association between yield and yield components may serve to identify key characters for selection along with grain yield.

In the present study, Correlation coefficients of seed yield with yield attributing characters and also among yield attributing characters are presented in Table 6. Yield per plant was positively correlated with clusters of pod per plant (0.7518 and 0.6648) at genotypic and phenotypic levels, respectively. The negative correlation of yield at genotypic and phenotypic levels was observed significant with pods per cluster $(-0.5803$ and -0.3708$)$ and hundred seed weight (-0.3949 and 0.3596). A positive correlation of yield with pods per plant had also been reported by Biradar et al., (2007) and Peksen (2004) in cowpea. In order to select high yielding cowpea cultivars and to increase yield per plant, clusters of pods per plant should be taken into consideration. Tewari and Gautam (1989) found that pod yield was positively and significantly correlated with primary branches per plant, pods per cluster, clusters of pod per plant, 100-seed weight and seeds per pod. Similar results have been reported by Kutty et al., (2003).

Amongst the other characters positive significant correlation at both genotypic and phenotypic levels was observed between a number of characters viz., plant height and primary branches $(0.5218$ and 0.4306$)$, plant height and clusters of pod per plant $(0.5283$ and 0.4047), plant height and pod length (0.3606 and 0.3279 ), pods per cluster and hundred seed weight (0.9299 and 0.6292 ), seeds per pod and pod length (0.8339 and 0.5358). Besides these, a positive correlation only at the genotypic level was observed between pods per cluster and seeds per pod (0.3089).

Characters were found negatively associated with each other at both genotypic and phenotypic levels includes plant height and pods per cluster (-0.8021 and -0.4999), clusters of pod per plant and pods per cluster $(-0.7239$ and -0.4970$)$, clusters of pod per plant and hundred seed weight (-0.4644 and $0.4255)$. A significant negative correlation at genotypic level was also observed between plant height and hundred seed weight ($0.3445)$. 
Table.1 Cowpea varieties used as parents and their sources

\begin{tabular}{|l|l|l|l|}
\hline Parent No. & Varieties & Source & Type \\
\hline P1 & UPC-622 & GBPUA\&T, Pant nagar & Improved Cultivar \\
\hline P2 & UPC-287 & GBPUA\&T, Pant nagar & Improved Cultivar \\
\hline P3 & JCC-2 & Manipur & Local Cultivar \\
\hline P4 & JCC-3 & Manipur & Local Cultivar \\
\hline P5 & JCC-1 & Manipur & Local Cultivar \\
\hline P6 & JCC-4 & Manipur & Local Cultivar \\
\hline
\end{tabular}

Table.2 Meteorological data during the experimental period at Instructional cum Research Farm, Assam Agricultural University, Jorhat

\begin{tabular}{|c|c|c|c|c|c|c|}
\hline \multirow[t]{2}{*}{ Period } & \multicolumn{2}{|c|}{ Temperature $\left({ }^{\circ} \mathbf{C}\right)$} & \multicolumn{2}{|c|}{$\begin{array}{c}\text { Relative Humidity } \\
(\%)\end{array}$} & \multirow{2}{*}{$\begin{array}{c}\text { Total } \\
\text { BSSH } \\
\text { (hrs) }\end{array}$} & \multirow[t]{2}{*}{$\begin{array}{l}\text { Total RF } \\
\quad(\mathrm{mm})\end{array}$} \\
\hline & Max. & Min. & Morn. & Even. & & \\
\hline October & 33.5 & 21.7 & 95 & 73 & 207.0 & 77.2 \\
\hline November & 28.4 & 16.6 & 94 & 69 & 214.1 & 1.2 \\
\hline December & 25.5 & 11.1 & 97 & 60 & 205.1 & 0.0 \\
\hline January & 25.1 & 10.8 & 95 & 57 & 199.6 & 4.3 \\
\hline February & 26.0 & 12.4 & 93 & 59 & 136.4 & 23.4 \\
\hline March & 29.8 & 16.1 & 90 & 55 & 154.6 & 42.7 \\
\hline
\end{tabular}


Table.3 Analysis of variance for yield and yield attributing characters

\begin{tabular}{|c|c|c|c|c|c|c|c|c|c|}
\hline \multirow{2}{*}{$\begin{array}{l}\text { Source of } \\
\text { Variation }\end{array}$} & \multirow{2}{*}{ d.f. } & \multicolumn{8}{|c|}{ Mean sum of squares } \\
\hline & & $\begin{array}{l}\text { Plant } \\
\text { height }(\mathrm{cm})\end{array}$ & $\begin{array}{l}\text { No. of } \\
\text { Primary } \\
\text { branches }\end{array}$ & Clusters/plant & $\begin{array}{l}\text { Pods } \\
\text { / cluster }\end{array}$ & $\begin{array}{l}\text { Seeds } \\
\text { / pod }\end{array}$ & $\begin{array}{l}\text { Pod length } \\
(\mathrm{cm})\end{array}$ & $\begin{array}{l}\text { Seed yield / } \\
\text { plant (gm) }\end{array}$ & $\begin{array}{l}100 \text { seed } \\
\text { weight } \\
\text { (gm) }\end{array}$ \\
\hline Replication & 1 & 342.286 & $2.881 * *$ & 0.975 & 0.264 & 0.079 & 0.138 & 186.524 & $\mathbf{0}$ \\
\hline Genotypes & 20 & $1057.676^{* *}$ & $1.355 * *$ & $9.157 * *$ & $0.303 *$ & $2.155 *$ & $1.963 *$ & $1445.760 * *$ & $0.054 * *$ \\
\hline Parent & 5 & 241.216 & 0.347 & $1.919 *$ & 0.054 & 2.149 & 1.622 & $351.955^{* *}$ & $0.053 * *$ \\
\hline Cross & 14 & $1188.415^{* *}$ & $1.812 * *$ & $5.809 * *$ & $0.385 * *$ & $1.896 *$ & 1.68 & $1672.771 * *$ & $0.056 * *$ \\
\hline P Vs C & 1 & $3309.622 * *$ & 0.006 & $92.215 * *$ & 0.394 & $5.810 *$ & $7.633 * *$ & $3736.625 * *$ & $0.025 * *$ \\
\hline Error & 20 & 198.314 & 0.149 & 0.619 & 0.103 & 0.816 & 0.765 & 61.11 & 0.002 \\
\hline
\end{tabular}

*Significant at $\mathrm{P}=0.05$ and ${ }^{* *}$ Significant at $\mathrm{P}=0.01$

Table.4 Estimates of genetic variance and related parameters for yield and yield attributing characters

\begin{tabular}{|c|c|c|c|c|c|c|c|c|}
\hline \multirow{2}{*}{$\begin{array}{l}\text { Genetic } \\
\text { component }\end{array}$} & \multicolumn{8}{|l|}{ Characters } \\
\hline & $\begin{array}{l}\text { Plant height } \\
(\mathrm{cm})\end{array}$ & $\begin{array}{l}\text { No. of } \\
\text { Primary } \\
\text { branches }\end{array}$ & $\begin{array}{l}\text { Clusters/ } \\
\text { plant }\end{array}$ & $\begin{array}{l}\text { Pods/ } \\
\text { cluster }\end{array}$ & Seeds / pod & $\begin{array}{l}\text { Pod length } \\
(\mathrm{cm})\end{array}$ & $\begin{array}{l}\text { Seed yield/ } \\
\text { plant (gm) }\end{array}$ & $\begin{array}{l}100 \text { seed } \\
\text { weight } \\
(\mathrm{gm})\end{array}$ \\
\hline GCV & 18.816 & 15.965 & 11.174 & 11.264 & 5.783 & 5.59 & 10.981 & 1.636 \\
\hline PCV & 22.748 & 17.826 & 11.957 & 16.07 & 8.612 & 8.437 & 11.456 & 1.699 \\
\hline$h^{2}(b s)$ & 0.684 & 0.802 & 0.873 & 0.491 & 0.451 & 0.439 & 0.919 & 0.927 \\
\hline GA AS $(\%)$ mean & 32.062 & 29.455 & 21.511 & 16.264 & 7.999 & 7.63 & 21.685 & 3.244 \\
\hline
\end{tabular}


Table.5 Mean performance of six parents and fifteen crosses in respect of different characters

\begin{tabular}{|c|c|c|c|c|c|c|c|c|}
\hline \multirow[t]{2}{*}{ Genotypes } & \multicolumn{8}{|l|}{ Characters } \\
\hline & $\begin{array}{l}\text { Plant height } \\
(\mathrm{cm})\end{array}$ & $\begin{array}{l}\text { No. of Primary } \\
\text { branches }\end{array}$ & $\begin{array}{l}\text { Clusters/ } \\
\text { plant }\end{array}$ & $\begin{array}{l}\text { Pods/ } \\
\text { cluster }\end{array}$ & Seeds / pod & $\begin{array}{l}\text { Pod length } \\
(\mathrm{cm})\end{array}$ & $\begin{array}{l}\text { Seed yield/ } \\
\text { plant (gm) }\end{array}$ & $\begin{array}{l}100 \quad \text { seed } \\
\text { weight }(\mathrm{gm})\end{array}$ \\
\hline \multicolumn{9}{|c|}{ ( } \\
\hline UPC-622 & 107.5 & 5.6 & 19.4 & 2.9 & 15.95 & 16.1 & 249.705 & 10.09 \\
\hline UPC-287 & 134.5 & 4.5 & 21.9 & 2.7 & 15.05 & 15 & 241.2 & 9.79 \\
\hline JCC-2 & 125.7 & 4.8 & 19.95 & 2.6 & 13.8 & 13.96 & 249.3 & 9.59 \\
\hline JCC-3 & 120.2 & 4.5 & 21 & 2.4 & 14.4 & 14.37 & 256.8 & 9.745 \\
\hline JCC-1 & 137.6 & 5.1 & 21.05 & 2.7 & 15.8 & 14 & 250.48 & 9.835 \\
\hline JCC-4 & 119.7 & 4.8 & 21.7 & 2.6 & 13.44 & 13.67 & 279.63 & 9.82 \\
\hline \multicolumn{9}{|l|}{ CROSSES } \\
\hline UPC-622 X UPC-287 & 93.1 & 4.43 & 15.5 & 3.765 & 15.95 & 15.55 & 195.125 & 10.045 \\
\hline UPC-622 X JCC-2 & 85.4 & 3.7 & 14.85 & 3.5 & 14.8 & 14.48 & 202.3 & 10.095 \\
\hline UPC-622 X JCC-3 & 145.2 & 5.6 & 18.15 & 2.6 & 13.9 & 14 & 232.6 & 10.08 \\
\hline UPC-622 X JCC-1 & 82.5 & 4 & 15.5 & 3.5 & 13.9 & 11.885 & 238.5 & 10.12 \\
\hline UPC-622 X JCC-4 & 79.8 & 4.85 & 17.7 & 3.35 & 11.8 & 12.82 & 220 & 10.105 \\
\hline UPC-287 X JCC-2 & 102.25 & 4.1 & 18.65 & 2.85 & 13.45 & 13.45 & 238 & 9.825 \\
\hline UPC-287 X JCC-3 & 110.4 & 4.8 & 17.7 & 2.4 & 14.4 & 14.03 & 222.95 & 9.8 \\
\hline UPC-287 X JCC-1 & 126.2 & 6.8 & 16.75 & 2.6 & 14.1 & 14.18 & 248.75 & 9.7 \\
\hline UPC-287 X JCC-4 & 88.2 & 5.2 & 16.3 & 2.8 & 12.9 & 12.5 & 233.145 & 9.79 \\
\hline JCC-2 X JCC-3 & 123.5 & 6.85 & 20.3 & 2.6 & 14 & 12.85 & 258.85 & 9.69 \\
\hline JCC-2 X JCC-1 & 86.3 & 3.9 & 17.7 & 2.7 & 13.4 & 13.8 & 202.17 & 9.75 \\
\hline JCC-2 X JCC-4 & 155.4 & 5.13 & 16.5 & 2.4 & 13.1 & 14.2 & 198.21 & 9.775 \\
\hline JCC-3 X JCC-1 & 74.1 & 4.6 & 17.75 & 2.7 & 14.05 & 13.1 & 239.8 & 9.705 \\
\hline JCC-3 X JCC-4 & 102.2 & 4.6 & 20.55 & 2.6 & 15.1 & 12.92 & 282.85 & 9.755 \\
\hline JCC-1 XJCC-4 & 113.7 & 4.3 & 19.4 & 2.6 & 13.9 & 13.83 & 291.35 & 9.76 \\
\hline Mean of parents & 124.2 & 4.88 & 20.83 & 2.65 & 14.74 & 14.52 & 254.52 & 9.81 \\
\hline Mean of crosses & 104.55 & 4.86 & 17.55 & 2.86 & 13.92 & 13.57 & 233.64 & 9.87 \\
\hline C.V. & 12.78 & 7.93 & 4.26 & 11.46 & 6.38 & 6.32 & 3.27 & 0.46 \\
\hline S.Ed & 9.96 & 0.27 & 0.56 & 0.23 & 0.63 & 0.62 & 5.53 & 0.03 \\
\hline CD $(5 \%)$ & 29.38 & 0.80 & 1.64 & 0.67 & 1.88 & 1.82 & 16.30 & 0.095 \\
\hline
\end{tabular}


Table.6 Phenotypic (above diagonal) and genotypic (below diagonal) correlation coefficients among yield and its attributes

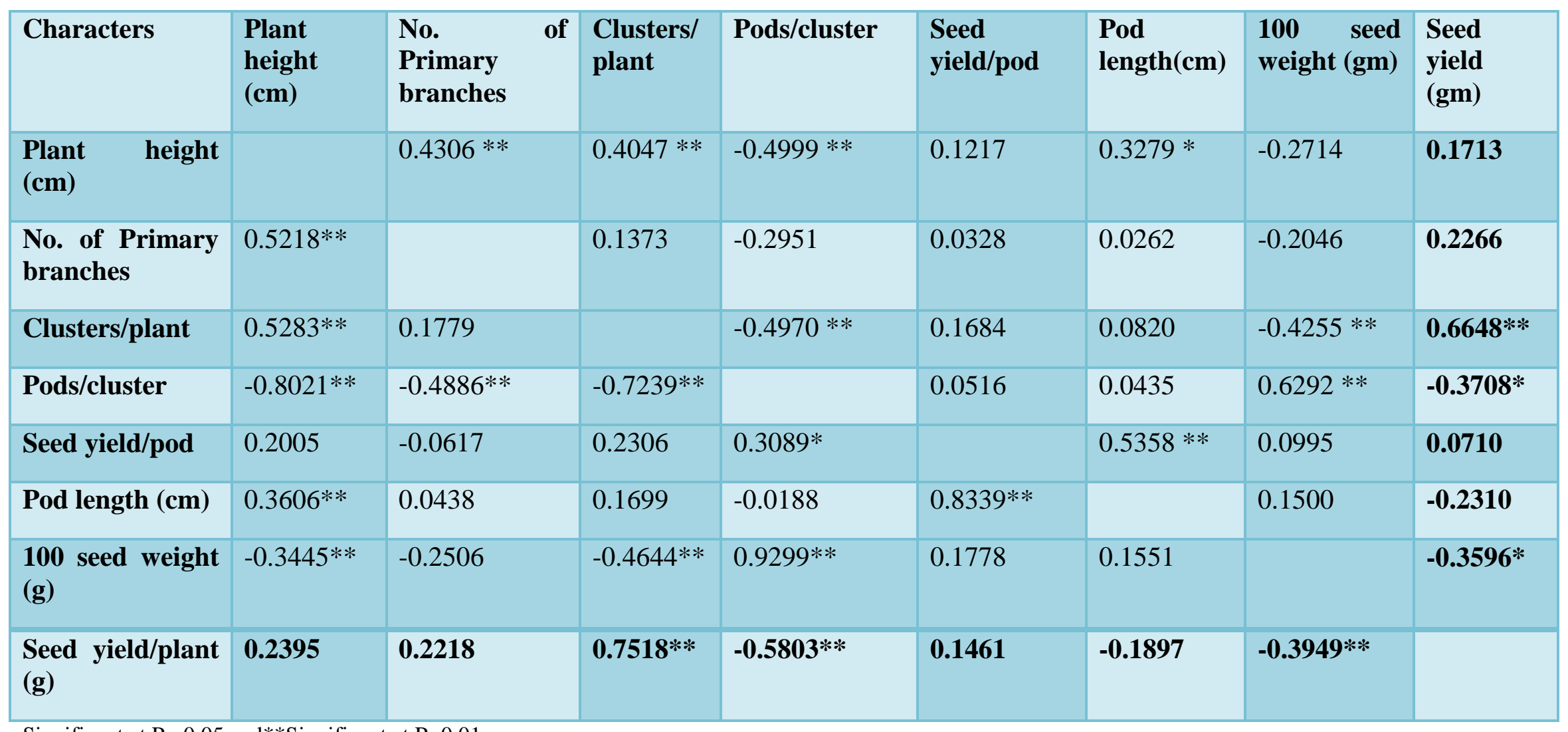

Significant at $\mathrm{P}=0.05$ and $* *$ Significant at $\mathrm{P}=0.01$ 
Fig.1 Path diagram at phenotypic level

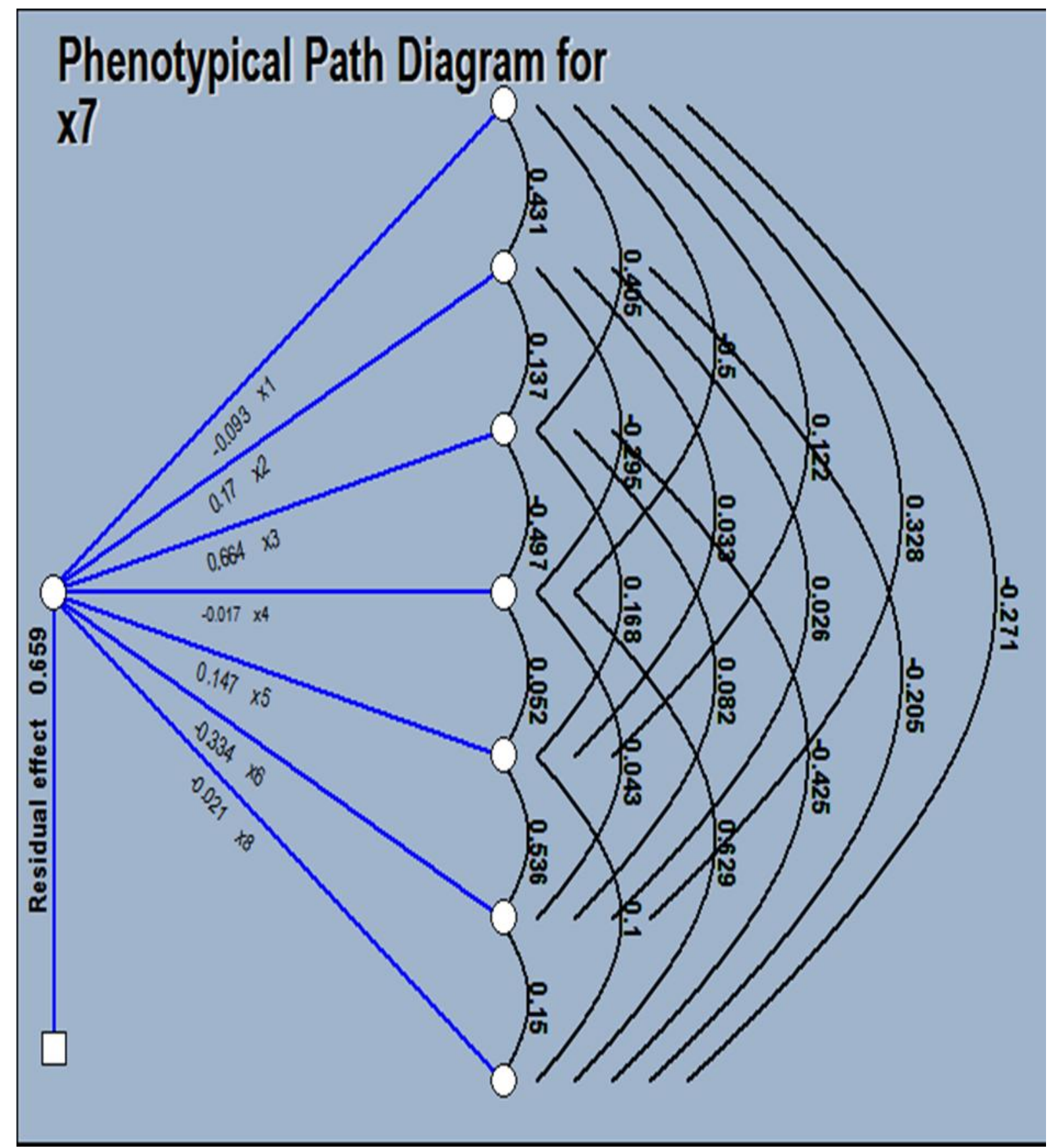

$\mathrm{x} 1=$ Plant height, $\mathrm{x} 2=$ No. of primary branches, $\mathrm{x} 3=$ Clusters of pod per plant, $\mathrm{x} 4=$ Pods per cluster, $\mathrm{x} 5=$ Seeds per pod, $x 6=$ Pod length, $x 7=$ Seed yield per plant, $x 8=100$ seed weight 


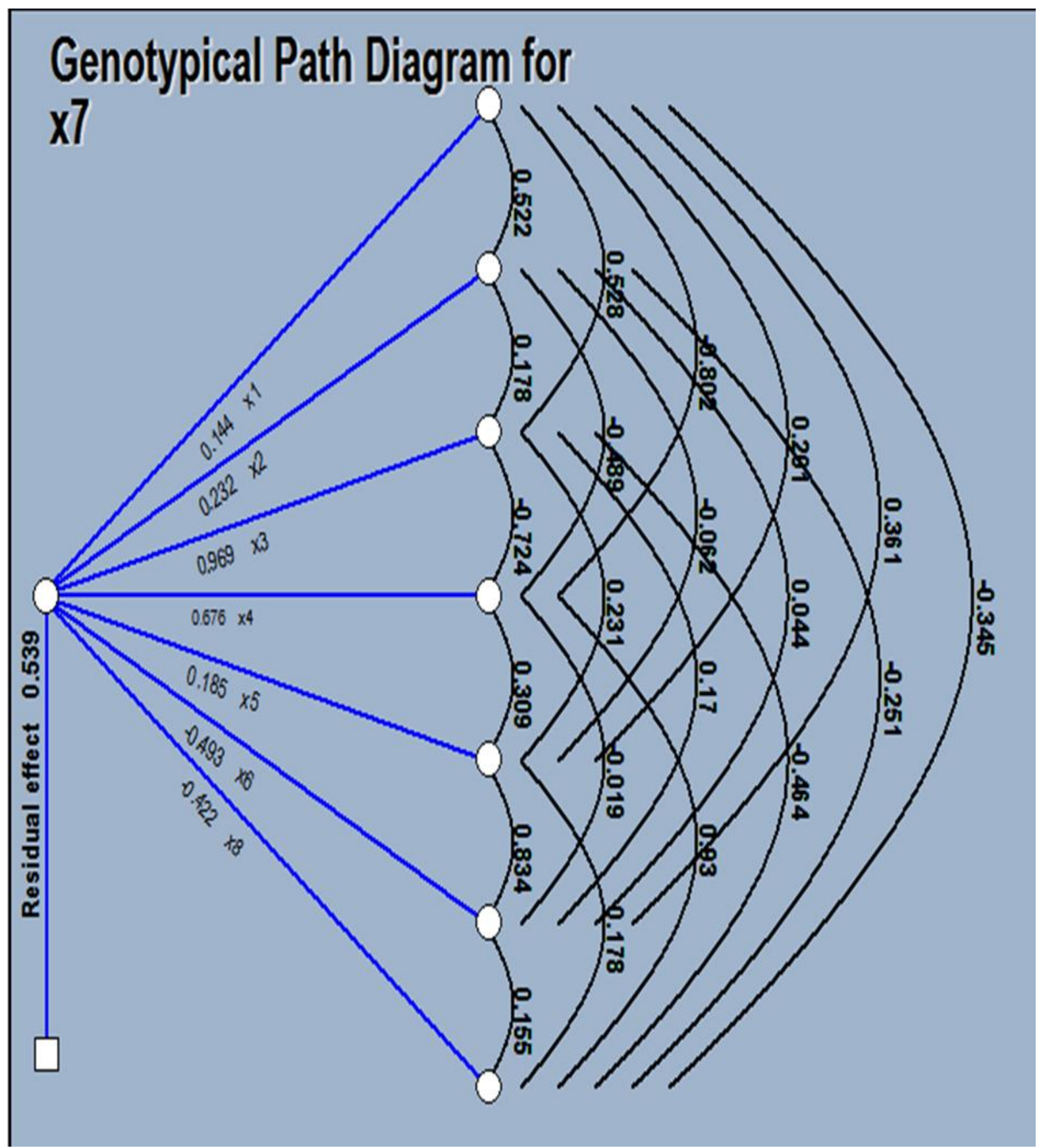

$\mathrm{x} 1=$ Plant height, $\mathrm{x} 2=$ No. of primary branches, $\mathrm{x} 3=$ Clusters of pod per plant, $\mathrm{x} 4=$ Pods per cluster, $\mathrm{x} 5=$ Seeds per pod, $x 6=$ Pod length, $x 7=$ Seed yield per plant, $x 8=100$ seed weight. 
It is ultimately the clusters of pods, which is important for realizing higher productivity as evident from very high and positive association between these two traits. Similar association was reported by Mathur (1995) and Lal et al., (2014). It is obvious from the study that selection on the basis of pods per plant and grain yield per plant in segregating populations of cowpea will be more effective in the development of promising genotypes. However, positive correlation of plant height with clusters of pod per plant, number of primary branches and pod length signifies possibility of indirect selection.

\section{Path coefficient analysis}

To understand the cause-effect relationship between yield attributes and seed yield, path coefficient analysis was performed both at phenotypic and genotypic levels and respective path diagrams are presented in Figure 1 and 2.

Path analysis at phenotypic level revealed that clusters of pod per plant (0.6645) had the maximum direct effect on seed yield followed by primary branches $(0.1701)$ and seed yield per pod (0.1468). While pod length (-0.3341) followed by plant height $(-0.0932)$, hundred seed weight (-0.0214) and pods per cluster (0.0165) exhibited highest negative direct effect respectively. The highest positive indirect effect was exhibited by plant height via clusters of pod per plant (0.2689) followed by seed yield per pod via clusters of pod per plant (0.1119), pod length via seed yield per pod (0.0786) and plant height via number of primary branches (0.0733). The residual effect was 0.6590 . Pods per cluster via clusters of pod per plant $(-0.3303)$ followed by hundred seed weight via clusters of pod per plant $(-0.2827)$, seed yield per pod via pod length $(-0.179)$ and plant height via pod length $(-0.1095)$ had the highest negative indirect effect on seed yield.
Path analysis at genotypic level revealed that clusters of pod per plant (0.9686) had the maximum direct effect on seed yield followed by pods per cluster $(0.6759)$, number of primary branches $(0.2316)$, seed yield per pod (0.1853) and plant height (0.1441) respectively, while pod length(-0.4927) and hundred seed weight $(-0.4225)$ exhibited highest negative direct effect respectively. Among the indirect effects, hundred seed weight via pods per cluster (0.6286) followed by plant height via clusters of pod per plant (0.5117) had the maximum positive indirect effect on seed yield. On the other hand pods per cluster via clusters of pod per plant (0.7011) followed by plant height via pods per cluster (-0.5422), clusters of pod per plant via pods per cluster (-0.4893), hundred seed weight via clusters of pod per plant $(-0.4498)$ and seeds per pod via pod length (-0.4109) had high negative indirect effect on seed yield. The residual effect obtained was 0.5392 .

Path analysis revealed that clusters of pod per plant, primary branches and seed yield per pod both at phenotypic and genotypic levels and plant height at genotypic level only exhibited high positive direct effect on seed yield per plant. Amongst these characters clusters of pod per plant also exhibited significant correlation with seed yield per plant both at phenotypic and genotypic levels. Clusters of pod per plant could be considered as the most potent character contributing towards increasing seed yield and deserve top most priority for inclusion as selection criteria for improvement of cowpea genotypes. Nwofia et al., (2012) reported number of pods/plant, number of leaves/plant and pod length had positive direct effects of varying magnitudes to seed yield. Similar results were also reported by Shanko et al., (2014) in which number of pods per plant exerted the maximum positive direct effect on seed yield phenotypically. 
In conclusion, analysis of variance for the characters revealed highly significant variations among the genotypes for yield and yield attributing characters. Further, it was observed that the parents, crosses as well as parents vs. crosses showed significant variations for most of the characters studied. Among the parents JCC-4 showed the best mean performance for seed yield per plant. Among the cross JCC-1 X JCC-4 exhibited the highest mean performance for seed yield per plant. Considering yield attributing characters the highest GCV was obtained for plant height. Heritability was highest for hundred seed weight and expected genetic advance was found highest for plant height. Yield per plant was positively and significantly correlated with clusters of pod per plant at both genotypic and phenotypic levels. Seed yield per plant was negatively correlated with pods per cluster and hundred seed weight at both genotypic and phenotypic levels. Path analysis revealed that clusters of pod per plant, primary branches and seed yield per pod exhibited high positive direct effect on seed yield per plant at phenotypic level and at genotypic level clusters of pod per plant, pods per cluster, number of primary branches, seed yield per pod and plant height had the maximum direct effect on seed yield.

\section{References}

Allard, R.W. (1960). Principles of plant breeding. New York; John Wiley and Sons Inc. 485 pp.

Amorim, E.P., Ramos N.P., Ungaro MRG and kiihl TAM (2008) Correlações e análise de trilhaemgirassol. Bragantia 67: 307316.

Ansari, B.A., and Khund, K.A., (2004). Aextent of heterosis and heritability in some quantitative characters of bread wheat. Indus. J. Pl. Sci. 3:189-192.

Biradar, S.,Salimath, P.M. and Sridevi, O. (2007). Association studies in the three segregating populations of Cowpea
(Vigna unguiculata (L.) Walp.).

Karnataka J. Agric. Sci. 20(2): 252-254.

Burton, G.W., DeVane, E.M (1953).

Estimating heritability in tall fescue (Festuca arundinaceae) from replicated clonal material. Agron. J., 45:478-481.

Burton, G.W., (1952). Quantitative inheritance in grasses. Prog. 6th Grassld. Cong. 1: 277-283.

Carsky, R.J., Vanlauwe, B. and Lyasse, O. (2002). Cowpea rotation as a resource management technology for cerealbased systems in the savannas of West Africa. In: Challenges and Opportunities for Enhancing Sustainable Cowpea Production.

Fatokun, C.A., Tarawali, S.A, Singh, B.B., Kormawa, P.M. and Tamo, M. (eds). International Institute of Tropical Agriculture, Ibadan, Nigeria, pp. 252266.

Damarany, A.M., (1994). Estimates of genotypic and phenotypic correlation, heritability and potency of gene set in Cowpea [Vigna unguiculata (L.) Walp.]. Assuit J. Agric. Sci., 25: 1-8.

Dewey, D.I. and Lu, K.H. (1959) A Correlation and Path-Coefficient Analysis of Components of Crested Wheatgrass Seed Production. Agronomy Journal, 51, 515-518.

Drabo, I., Redden, R., Smithson, J.B. and Aggarwah, V.D. (1984). Inheritance of seed size in cowpea (Vigna unguiculata (L.) Walp.). Euphytica33: 929-934.

Ehlers, J.D., and Hall, A.E. (1996). Genotypic classification of cowpea based on responses to heat and photoperiod. Crop Sci.36: 673-679.

Hanson C. H., Robinson H. F. and Comstock R. E. 1956, Biometric studies of yield in segregating populations of Korean Lespedeza, Agron. J., 43, 268-72.

Hanson, E.D., (1963). Heritability in statistical genetics and plant breeding: Natural academy of science, NRC, 
Washington, pp. 125-140.

Idahosa, D.O.,Alika, J.E. and Omoregie, A.U. (2010). Genetic variability, heritability and expected genetic advance as indices for yield and yield components selection in cowpea (Vigna unguiculata (L.) Walp. Acad. Arena2(5): 22-26.

Johnson, H.W., Robinson, H.F. and Comstock (1955). Estimation of genetic and environmental variability in soybeans. Agron. J. 47: 314-318.

Kumar, R.,Sangwan, R.S. and Singh, S. (2009). Genetic variability and heritability in cowpea [Vigna unguiculata (L.) Walp.]. Indian J. Plant Genet. Res. 22(1): 74-75.

Kumari,V., Arora, R.N., Singh, J.V., Kumari, V., Henry, A., Kumar, D. and Singh, N.B. (2003). Variability and path analysis in grain cowpea. Proceedings of the National Symposium on Arid Legumes, for Food Nutrition, Security and Promotion of Trade, Hisar, India. Advances in Arid Legumes Research, p 59-62.

Kutty, C.N.,Mili, R. and Jaikumaran, U. (2003). Correlation and path coefficient analysis in vegetable cowpea (Vigna unguiculata (L.) Walp.). Indian J. Hort. 60: 257-261.

Lal, D.R., Bhardwaj, V.N. and Singh, R. (2014). Hierarchical clustering and path analysis in cowpea (Vigna unguiculata L. Walp.). Ann. Plant Soil Res. 16(2): 159-163.

Lambot, C. (2002). Challenges and opportunities for enhancing sustainable cowpea production. Proceedings of the World Cowpea Conference III, International Institute of Tropical Agriculture (IITA), Ibadan, Nigeria, pp. 4-8.

Langyintuo, A.S., Lowenberg-DeBoer, J., Faye, M., Lambert D, Ibro G., Moussa, B.,Kergna, A.,Kushwaha, S., Musa, S. and Ntoukam, G. (2003). Cowpea supply and demand in West Africa. Field Crops Res. 82: 215-231.

Lopes, F.C.C., Gomes, R.L.F. and Filho, F.R.F. (2003). Genetic control of cowpea seed sizes. Sci. Agricol. 60 (2): 315-318.

Mathur, R. (1995). Genetic variability and correlation studies in segregating generations of cowpea. Madras Agril. J. 82: $150-152$.

Nehru, S.D.,Suvarna and Manjunath, A. (2009). Genetic variability and character association studies in cowpea in early and late kharif seasons. Legume Res. 32(4): 290-292.

Nwofia, G.E.,Nwanebu, M. and Agbo, C.U. (2012). Variability and InterRelationships between yield and associated traits in cowpea (Vigna unguiculata (L.) Walp as influenced by plant populations. World J. Agril. Sci. 8 (4): 396-402.

Olapade, A.A., Okafor, G.I.,Ozumba, A.U. and Alatunji, O. (2002). Characterization of common Nigeria cowpea (Vigna unguiculata L. Walp). Food Engg. 55: 101-105.

Omoigui, L.O., Ishiyaku, M.F., Kamara, A.Y., Alabi, S.O., Mohammed, S.G. (2006). Genetic variability and heritability studies of some reproductive traits in cowpea [Vigna unguiculata (L.) Walp.]. Afr. J. Biotechnol., 5(13):11911195.

Pathmanathan U, Ariyanayagam RP, Haque SO (1997). Genetic analysis of yield and its components in vegetable cowpea [Vigna unguiculata (L.) Walp.] Euphytica, 92(2): 207-213.

Peksen, A. (2004). Fresh pod yield and some pod characteristics of Cowpea (Vigna unguiculata L. Walp.) Genotypes from Turkey. Asian J. Plant Sci.3: 269-273.

Shanko, D.,Andargie, M. and Zelleke, H. (2014). Genetic variability and heritability of yield and related 
characters in cowpea (Vigna unguiculata L. Walp.). Res. Plant Biol. $4(2): 21-26$.

Shivakumar (2013). Genetic variability and heritability studies in bush cowpea (Vigna unguiculata (L.) Walp.). Legume Genom. Genet. 4(4): 27-31.

Singh, B.B., Ajeigbe, H.A., Tarawali, S.A., Fernandez-Rivera, S. and Abubakar, M. (2003). Improving the production and utilization of cowpea as food and fodder. Field Crops Res. 84: 169-177.

Taiwo, K.A. (1998). The potential of cowpea as human food in Nigeria. Technovation. 18 (6/7): 469-481.

Tewari, A.K. and Gautam, N.C. (1989). Correlation and path coefficient analysis in cowpea (Vigna unguiculata L. Walp.). Indian J. Hort. 46: 516-521.

Ubi, E.B.,Mignouna, H. and Obigbesan, G. (2001). Segregation for seed weight, pod length and days to flowering following cowpea cross. African Crop
Sci. J. 9(3): 463-470.

Uguru, M.I.,(1995). Heritable relationships and variability of yield and yield components in vegetable Cowpea. Afr. Crop Sci. J., 3(1): 23-28.

Umaharan, P., Ariyanayagan, R.P., Haque, S.Q. (1997). Genetic analysis of yield and its components in vegetable cowpea [Vigna unguiculata (L.) Walp.]. Euphytica, 7: 207-213.

Umaharan, P.,Ariyanayagan, R.P. and Haque, S.Q. (1997). Genetic analysis of yield and its components in vegetable cowpea [Vigna unguiculata (L.) Walp.]. Euphytica. 7: 207-213.

Verdcourt, B., 1970. Studies in Leguminosaepapilionaideae for the flora of tropical east Africa. Kew Bull., 24: 507-569.

Yalcin, I., (2007). Physical properties of cowpea (Vigna sinensis L) seed. J. Food Eng. 79 (1): 57-62.

\section{How to cite this article:}

Das, R.R., P. Talukdar, Praveen Kumar and Neog, S.B. 2018. Relationship among Different Secondary Traits and Seed Yield in Cowpea (Vigna unguiculata L. Walp). Int.J.Curr.Microbiol.App.Sci. 7(02): 1382-1396. doi: https://doi.org/10.20546/ijcmas.2018.702.167 